\title{
Populist Constitutionalism
}

VB verfassungsblog.de/populist-constitutionalism/

Paul Blokker Do 4 Mai 2017

Do 4 Mai

2017

Populist engagement with constitution-making and constitutional reform forms a distinctive, and in significant ways worrying, tendency. Populism is explicitly present in the constitutional politics of the East-Central European countries of Hungary and Poland (but not reducible to East-Central Europe), and is causing important tensions in the European Union, which proclaims to be grounded in the values of democracy, the rule of law, and fundamental rights. Concern about the populist-constitutional phenomenon has stimulated lively debates on democratic backsliding and illiberal democracy in Europe as well as on the supranational monitoring of democracy. ${ }^{1}$ See $C$. Closa and D. Kochenov (2016) (eds), Reinforcing the Rule of Law Oversight in the European Union, Cambridge University Press.

Populism is generally seen as in great tension with constitutionalism, that is, populism rejects the modern constitutional order tout court or, at best, relates to constitutionalism in an opportunistic way. In my view, however, concurring here with Jan-Werner Müller, a distinctive populist approach to constitutionalism warrants further investigation. ${ }^{2}$ A more expanded argument is to appear in C. De La Torre (ed.), Routledge International Handbook of Global Populism, Routledge. There at least three different reasons for this. First of all, the idea of popular sovereignty is central to populism, but the people's will is equally the ultimate legitimation of modern constitutionalism. Indeed, the modern constitutional tradition is grounded in both order and self-limitation, and popular self-government. ${ }^{3)}$ Cf. P. Blokker (2017), 'The Imaginary Constitution of Constitutions', Social Imaginaries, 3:1. What is specific is that populists claim that the principle of popular sovereignty is insufficiently guaranteed in liberal-constitutional regimes. Secondly, populism engages in legal skepticism, or what I have elsewhere called legal resentment, ${ }^{4}$ P. Blokker (2013). New democracies in crisis?: a comparative constitutional study of the Czech Republic, Hungary, Poland, Romania and Slovakia, Routledge. that is, populists are both highly critical of liberal or legal constitutionalism and they endorse alternative constitutional projects. Populist constitutionalism can thus be understood as a critical countercurrent. Following from this, thirdly, populism frequently engages in projects of constitution-making and constitutional reform. Populists in power engage in intense reform (and abuse) of the existing constitutional arrangements, in contrast to the idea that populism consists of a merely oppositional, antipolitical phenomenon.

\section{Constitutionalism and popular sovereignty}

Populism is generally understood as the negation of constitutional democracy. Populists are seen as impatient with procedures and institutions, and as loath of intermediary bodies, as they prefer unmediated relations between the populist ruler and the people. Populists prefer direct, unmediated and natural or pure forms of politics, in contrast to indirect and artificial ones. $\left.{ }^{5}\right) \mathrm{N}$. Urbinati (1998), 'Democracy and populism', Constellations, 5(1), 110-124, 111.

But the populist approach towards constitutionalism is not merely negative or abusive, as not least becomes evident from the projects of constitution-making and constitutional reform as have emerged in (highly diverse) cases in Latin America and East-Central Europe. As recently suggested by Luigi Corrias, ${ }^{6}$ L. Corrias (2016), 'Populism in a Constitutional Key: Constituent Power, Popular Sovereignty and Constitutional Identity', European Constitutional Law Review, 12(01), pp. 6-26. populism can be related to a specific - revolutionary and democratic - constitutional tradition. The revolutionary tradition emphasizes constituent power, understood as a founding act of the people, founding the polity anew. As Corrias argues, the understanding of the constituent power of the people in the revolutionary tradition appears as almost absolute, and as potentially being exercised directly in the polity. ${ }^{7}$ Corrias (n 6) 16. What further emerges is a primacy of politics over law in the revolutionary tradition. Law is ultimately the 
outcome of political action, not the other way around.

This dimension is well-reflected in a statement by Jarosław Kaczyński, the eminence grise of the Polish Law and Justice Party (PiS),

\begin{abstract}
(...) the state based on the rule of law does not have to be a democratic state. In a democracy, the only sovereign is the nation. The parliament and, in the Polish conditions, the President are its representatives. These two state organs are responsible for the creation of law. To these bodies belongs the control over our lives. ${ }^{8)}$ Cited in A. Balcer (2017), 'Beneath the surface of illiberalism', WiseEuropa, p. 47. The frequent changes of the Hungarian Fundamental Law adopted in 2011 equally point to a primacy of politics.
\end{abstract}

The revolutionary understanding of constitutionalism is in tension with a second tradition, the evolutionary tradition, which understands constitutionalism as a negative, limiting instrument, and which seeks to create order and stability and to 'tame politics' ${ }^{9}$ ) Corrias ( $n$ 6) 15. The pedigree of this understanding of constitutionalism is less a democratic one, but rather related to liberal and statist understandings of constitutionalism. The evolutionary approach is endorsing a primacy of the law over politics, displaying a certain distrust of the people and of popular sovereignty, and understanding popular politics as potentially threatening the constitutional order itself. It may be argued that whereas the revolutionary tradition keeps the idea of constituent power alive in the constituted order, in the evolutionary approach, constituent power is seen as absorbed in (the institutions of) constituted power.

The populist understanding of constitutionalism hinges on the revolutionary tradition, but with a specific twist. Populism captures the popular will and claims it its own, against other social forces, in- or outside society. Populists tend to define the people in strong contrast to significant Others (elites, non-natives, foreign forces), and in this turn their (idealized) construction of the people into the only acceptable, non-corrupted one. The people is in this equated with a self-constructed populist majority, understood in contrast to minorities. The rule of law and constitutionalism cannot, according to populists, override the 'real' popular will. Constitutionalism as such becomes a device in the populist project of rebuilding the state.

\title{
Legal resentment
}

Populism is less the anti-thesis of constitutional law as such, in that it constitutes a critical approach to liberal or legal constitutionalism. The populist, critical attitude, or 'legal resentment', ${ }^{10}{ }^{2}$ Resentment of liberal legalism is not the same as populist constitutionalism. Radical and participatory democrats equally criticize liberalism and representative democracy, but come, on the basis of a sometimes similar critique, to very different positive programmes of constitutional democracy. consists in a critical stance towards liberal constitutionalism, and liberalism's juridification and rationalization of society. In important ways, this attitude might be related to a Schmittian understanding of the constitution, ${ }^{11) C f . ~ A . ~ A n t a l ~(2017), ~ ' T h e ~ P o l i t i c a l ~ T h e o r i e s, ~ P r e c o n d i t i o n s ~ a n d ~}$ Dangers of the Governing Populism in Hungary', Politologický časopis-Czech Journal of Political Science, 24(1), 520; P. Kahn (2011), Political theology: four new chapters on the concept of sovereignty, Columbia University Press. and to Carl Schmitt's critique of liberal constitutionalism and its conception of the rule of law. ${ }^{12)}$ Cf. E.W. Böckenförde, E. W. (1997), 'The Concept of the Political: A Key to Understanding Carl Schmitt's Constitutional Theory', The Canadian Journal of Law and Jurisprudence, 10(01), pp. 5-19. A Schmittian view of constitutionalism understands the constitution as an expression of political unity and as a protection of the state's existence. It does not accept the idea of the constitution as a higher law, emanating from a foundational or basic norm, or the idea of an independent apex court guarding the constitution, but rather emphasizes the primacy of the political.

In populism, four dimensions of legal resentment stand out, indicating a problematic relation to the liberal ideas of 
the rule of law and constitutionalism. First, the liberal, 'neutral' understanding of the rule of law is criticized as an obstacle to achieving political unity or to protect the existence of the collectivity. The rule of law is not the framework of the decision-making process, according to populists, but rather the vehicle of the decisions of the true representatives of the People. Second, the indirect, representative and pluralistic view of democracy found in liberalism is contested, as it creates a division in society between rulers and ruled. The proceduralism of liberal democracy (checks and balances, division of powers, parliamentary debate, rights of the opposition) is contested as cumbersome and artificial, and as constraining the true political will of the People. Third, the collectivity comes prior to the individual, and, hence, an unmediated endorsement of individualistic and universalistic human rights is viewed with suspicion. Human rights form in this reading potential obstacles to, and a relativization of, the political community, and need to be reformulated in the interest of the latter. As Viktor Orbán claimed in a seminal speech pronounced in Romania in 2014, [the]

\begin{abstract}
Hungarian nation is not a simple sum of individuals, but a community that needs to be organized, strengthened and developed, and in this sense, the new state that we are building is an illiberal state, a non-liberal state. It does not deny foundational values of liberalism, as freedom, etc.. But it does not make this ideology a central element of state organization, but applies a specific, national, particular approach in its stead.
\end{abstract}

Fourth, there is a great suspicion of law and judicial decisions stemming from outside of the domestic arena. A universalistic interpretation of law and international norms, and in particular of human rights, is denied. Rather, human rights ought to be always applied in a national context by national judges. The critique is that international norms are not democratic (reflecting the popular will), and form an obstacle to domestic democratic decision-making in the name of the People. ${ }^{13}$ )This is not a critique merely heard in East-Central Europe. Barbara Oomen speaks of a 'human rights backlash' in discussing the case of the Netherlands, where since 2010 the legitimacy of the ECtHR is increasingly contested, see B.M. Oomen (2016), 'A serious case of Strasbourg-bashing? An evaluation of the debates on the legitimacy of the European Court of Human Rights in the Netherlands', The International Journal of Human Rights, 20(3), 407-425. Another obvious case is the UK, see K. Nash, K. (2016), 'Politicising human rights in Europe: Challenges to legal constitutionalism from the Left and the Right', The International Journal of Human Rights, pp. 1-14.

\title{
The populist constitutional programme
}

Populist projects of constitutionalism follow a different understanding of (constitutional) law. Populists emphasize the emancipation of the 'plebs' or victimized people, identified with some notion of what Claude Lefort has called the People-As-One, in which internal division is denied and the people constructed in deep opposition to some enemy. ${ }^{14)}$ Cf. C. Lefort (1986), The Political Forms of Modern Society: Bureaucracy, Democracy, Totalitarianism, Cambridge: The MIT Press. See for a detailed, historical account of Hungary and Poland, Balcer (n 8). Legal resentment in its negative dimension informs then positive alternative projects, found in 'illiberal constitutionalism'15)L. A. Thio (2012), 'Constitutionalism in illiberal Polities', Michel Rosenfeld and András Sajó (eds), The Oxford Handbook of Comparative Constitutional Law, Oxford University Press, pp. 133-152, 133. or 'counter-constitutionalism'. ${ }^{16)}$ K.L. Scheppele forthcoming (2017), 'The Social Lives of Constitutions', P. Blokker and C. Thornhill (eds), Sociological Constitutionalism, Cambridge University Press. What identifies such positive forms of constitutionalism is the perception of a 'common enemy' in liberal constitutionalism, and a critique of both the 'meta-liberal value of normative individualism' and its understanding of the 'neutral state'. Populist constitutionalism emphasizes community interests and the active promotion of a particular vision of communal life. If liberal constitutionalism emphasizes a 'court-centric rights-based constitutionalism', populist constitutionalism invokes a contrasting vision of individuals embedded in and owing allegiance to a given community, and endorses an understanding of constitutionalism as a means to protect a distinct community, its ethos, and its traditions. A 
communitarian view understands the individual as a 'socially embedded' self and the community as highly important in forming the individual. ${ }^{17)}$ Thio (n 16) 142.

Populist engagement with constitutions comes through in a variety of ways. First, as mentioned, in their political projects, populists actively take recourse to constitutional reform, not least in order to safeguard and perpetuate their political power in the name of a 'pure' people. Second, distinctive dimensions of populist constitutionalism equally emerge in the discourses and actions of other political actors, not necessarily or predominantly identified as populist. ${ }^{18)}$ This includes various examples of attempts at integrating populism into the political institutional system, as exemplified in the last decade by projects of constitutional reform in Italy, by both Silvio Berlusconi and recently Matteo Renzi, and in the very different case of Romania, by both the former president Traian Băsescu and his competitor, Victor Ponta, compare M. Shafir (2013), 'Neo-populism in the post-communist zodiac', in: S. Gherghina, S. Mişciou, and S. Soare (eds), Contemporary Populism: A Controversial Concept and Its Diverse Forms, Cambridge Scholars Publishing, pp. 316-355, 333. This indicates a potential diffusion of a populist-constitutional mindset into the political mainstream, which potentially leads to a wider erosion of liberal-constitutional ideals. It may also indicate more structural trends of change regarding the relation between democracy and constitutionalism. $A$ third matter regards the complexity of the claims that populists tend to make regarding constitutions, and the refined approach they sometimes take to constitutional law. As Gábor Halmai has argued, on various occasions the Hungarian populist regime has engaged with (constitutional) law in a relatively sophisticated way, for instance, when it invoked its right to defend Hungarian constitutional identity, or in its recent Lex CEU.

In sum, I believe a more in-depth understanding of the populist-constitutional phenomenon is necessary if we want to imagine, elaborate, and put into practice, valid democratic-constitutional alternatives. Manifestations of populist constitutionalism are signifiers of a deep discomfort with, and malfunctioning of, the existing institutions of liberal, representative democracy. It also indicates that a mere strengthening of the liberal, constitutional-democratic state including a strong and independent constitutional court - may not be sufficient nor effective as an antidote.

\section{References [+]}

1. $\uparrow$ See C. Closa and D. Kochenov (2016) (eds), Reinforcing the Rule of Law Oversight in the European Union, Cambridge University Press.

2. $\uparrow \quad$ A more expanded argument is to appear in C. De La Torre (ed.), Routledge International Handbook of Global Populism, Routledge.

3. $\uparrow$ Cf. P. Blokker (2017), 'The Imaginary Constitution of Constitutions', Social Imaginaries, 3:1.

4. $\uparrow$ P. Blokker (2013). New democracies in crisis?: a comparative constitutional study of the Czech Republic, Hungary, Poland, Romania and Slovakia, Routledge.

5. $\uparrow \quad$ N. Urbinati (1998), 'Democracy and populism', Constellations, 5(1), 110-124, 111.

6. $\uparrow \quad$ L. Corrias (2016), 'Populism in a Constitutional Key: Constituent Power, Popular Sovereignty and Constitutional Identity', European Constitutional Law Review, 12(01), pp. 6-26.

7. $\uparrow \quad$ Corrias (n 6) 16 .

8. $\uparrow$ Cited in A. Balcer (2017), 'Beneath the surface of illiberalism', WiseEuropa, p. 47. The frequent changes of the Hungarian Fundamental Law adopted in 2011 equally point to a primacy of politics.

9. $\uparrow \quad$ Corrias $(\mathrm{n} 6) 15$.

10. $\uparrow$ Resentment of liberal legalism is not the same as populist constitutionalism. Radical and participatory democrats equally criticize liberalism and representative democracy, but come, on the basis of a sometimes similar critique, to very different positive programmes of constitutional democracy. 
11. $\uparrow \quad$ Cf. A. Antal (2017), 'The Political Theories, Preconditions and Dangers of the Governing Populism in Hungary', Politologický časopis-Czech Journal of Political Science, 24(1), 5-20; P. Kahn (2011), Political theology: four new chapters on the concept of sovereignty, Columbia University Press.

12. $\uparrow \quad$ Cf. E.W. Böckenförde, E. W. (1997), 'The Concept of the Political: A Key to Understanding Carl Schmitt's Constitutional Theory', The Canadian Journal of Law and Jurisprudence, 10(01), pp. 5-19.

13. $\uparrow$ This is not a critique merely heard in East-Central Europe. Barbara Oomen speaks of a 'human rights backlash' in discussing the case of the Netherlands, where since 2010 the legitimacy of the ECtHR is increasingly contested, see B.M. Oomen (2016), 'A serious case of Strasbourg-bashing? An evaluation of the debates on the legitimacy of the European Court of Human Rights in the Netherlands', The International Journal of Human Rights, 20(3), 407-425. Another obvious case is the UK, see K. Nash, K. (2016), 'Politicising human rights in Europe: Challenges to legal constitutionalism from the Left and the Right', The International Journal of Human Rights, pp. 1-14.

14. $\uparrow \quad$ Cf. C. Lefort (1986), The Political Forms of Modern Society: Bureaucracy, Democracy, Totalitarianism, Cambridge: The MIT Press. See for a detailed, historical account of Hungary and Poland, Balcer (n 8).

15. $\uparrow \quad$ L. A. Thio (2012), 'Constitutionalism in illiberal Polities', Michel Rosenfeld and András Sajó (eds), The Oxford Handbook of Comparative Constitutional Law, Oxford University Press, pp. 133-152, 133.

16. $\uparrow \quad$ K.L. Scheppele forthcoming (2017), 'The Social Lives of Constitutions', P. Blokker and C. Thornhill (eds), Sociological Constitutionalism, Cambridge University Press.

17. $\uparrow \quad$ Thio (n 16) 142.

18. $\uparrow$ This includes various examples of attempts at integrating populism into the political institutional system, as exemplified in the last decade by projects of constitutional reform in Italy, by both Silvio Berlusconi and recently Matteo Renzi, and in the very different case of Romania, by both the former president Traian Băsescu and his competitor, Victor Ponta, compare M. Shafir (2013), 'Neo-populism in the postcommunist zodiac', in: S. Gherghina, S. Mişciou, and S. Soare (eds), Contemporary Populism: A Controversial Concept and Its Diverse Forms, Cambridge Scholars Publishing, pp. 316-355, 333.

LICENSED UNDER CC BY NC ND

SUGGESTED CITATION Blokker, Paul: Populist Constitutionalism, VerfBlog, 2017/5/04, http://verfassungsblog.de/populist-constitutionalism/, DOI: https://dx.doi.org/10.17176/20170504-220032. 